\title{
Fictions of Counterinsurgency
}

\author{
Louise Barnett
}

\section{Synopsis}

My essay examines the disconnect between theory and practice in the American response to terrorism, primarily by comparing the policies advocated in the revised U.S. Army/Marine Corps Counterinsurgency Field Manual (2006) with actual military practice in Afghanistan and Iraq. I refer to the official policies as "fictions" because they cannot be put into practice in any meaningful way: they create the illusion that military initiatives can effectively combat terrorism when their usual result is to breed more terrorism.

\section{Biography}

Louise Barnett is Professor of American Studies at Rutgers, the State University of New Jersey. Among her books are Atrocity and American Military Justice in Southeast Asia (Routledge, 2010), Touched by Fire: The Life, Death, and Mythic Afterlife of George Armstrong Custer (Holt, 1996. 1997; Nebraska, 2006).

\section{Essay}

The apparatus of counter-terrorism seems to be everywhere in our country today. One site is the massive bureaucracy of the National Security Agency, at the forefront of transforming the United States into a national surveillance state in which warrantless wiretapping of American citizens at home has been quietly-and many would say unconstitutionally--added to the original announced goal of wiretapping foreign communications. "At least two and a half million people hold confidential, secret, or top-secret clearances" (Mayer 48), and there are literally millions of classified documents.

Another aspect would be the changes in ordinary American life because of 9/11, from anti-Muslim sentiment and activity to the indignities of travel by plane. This domestic front will not be my topic although it, too, deploys many fictions: one example we have all had to deal with, annoyingly, is restricting our carry-on liquids to no more than $3 \mathrm{oz}$., as if this is an explosion-proof amount. It isn't. What purpose does this practice serve? If it does not guarantee safety, then it is undoubtedly intended to create the illusion of safety. There is also the fiction that all classes of people are equally likely to be terrorists, including greatgrandmothers, double amputees, cancer patients, and toddlers. It's no small irony that as our political system has less and less meaningful democracy, to use 
Chomsky's term, we have a kind of nonsensical democracy in a place where it doesn't belong. l'll leave the parsing of such policies to others.

And I don't even know where to put the knowledge that Guantánamo detainees are being urged to read Stephen Covey's The Seven Habits of Effective People (Frank 9-11). Today there's really too much stuff out there that you can't make up.

My topic will be, rather, the fictions of counterinsurgency, that form of unconventional warfare designed to defeat irregular enemy forces sometimes called insurgents or nonstate terrorists. (In Iraq, for awhile, Donald Rumsfeld tried to dismiss them as "dead-enders," but that was wishful thinking.) Counterinsurgency as a war tactic has a long history; as a strategy, it has been the chief mode of American military action in the 21st century, yet, as a strategy it is basically and irremediably flawed because of a simple truth: we cannot win the hearts and minds of a populace that is simultaneously being slaughtered by our soldiers. The rules of engagement make such slaughter both inevitable and frequent. Armies will always be better at destruction, which they are trained to do, than at nation-building.

The politicians who get the military into this kind of war give it a mission that it cannot succeed at. The generals then tell the politicians what they want to hear because that is how they advance their careers. Those who speak truth to power are speedily retired, witness Generals Eric Shinseki and Antonio Taguba. ${ }^{1}$ The men who do the actual killing are focused on returning home alive. These are the "facts on the ground," and they transcend the accident of whichever political party happens to hold power and whether there is an anti-war movement or not. A huge anti-war movement could not prevent 58,000 American deaths in Vietnam in a losing cause under both Democratic and Republican presidents. The almost total absence of an anti-war movement over the past ten years has not made it possible for our military to win in Afghanistan. As long as the military is guided by and promulgates fictions of counterinsurgency, success is out of the question--regardless of public opinion back home.

Here, just as in holding up the $3 \mathrm{oz}$. rule to examination, it is easy enough to simply open at random the most recent counterinsurgency field manual, the one created in 2006 under the impetus of General David Petraeus to reflect the most current military practice. We can read what we find there and compare it to the reality of our hottest war of the moment, Afghanistan. The fictions begin immediately. Generals Petraeus and James Amos, representing the Army and the Marine Corps, state in the forward to this manual: "A counterinsurgency campaign is.... mix of offensive, defensive, and stability operations conducted along multiple lines of operations." ${ }^{2}$ One can envision the PowerPoint pie chart in which each activity receives its precise percentage of the whole. This mix of operations sounds quite reassuring: it seems to cover all bases, while the "multiple lines of operations" is similarly suggestive of forethought, control, and 
comprehensiveness. Yes, "forethought, control, and comprehensiveness": it's so easy to imitate military-speak, and we're so used to empty abstractions like this that convey mastery without resorting to facts.

The forward continues by defining the task of actually conducting a counterinsurgency campaign: it will comprise "activities that soldiers and Marines have not been trained to do" (xlvi). That's hardly promising in a world that has more and more come to depend upon specialization and expertise. The generals go on to say that these fighting men and women "are expected to be nation builders as well as warriors" (xlvi). Could this be contradictory on some level? No, the generals describe it as merely challenging, daunting, and difficult--words that in the past would have characterized many a straightforward military mission.

Lieutenant Colonel John Nagl, an enthusiastic proponent of counterinsurgency, says the same thing as the counterinsurgency manual in his own way: "We need the ability to kill people and break things with our Army, absolutely. But we also need, in this modern era ... . an Army that can protect people and build things. And what we're doing is looking for the right balance between those two." ${ }^{3}$ Critics such as West Point professor Lt. Col. Gian Gentile argue--convincingly, in my opinion--that there can be no balance between these two antipodal activities. ${ }^{4}$ Conventional wars did the killing and breaking first; constructive activities followed, whereas, I've already noted, counterinsurgency requires both at the same time, a key reason for its failures in Vietnam, Iraq, and Afghanistan.

Furthermore, in conventional warfare the soldier or Marine would be prepared for the enemy to greet him with a hand grenade or other weapon while in the counterinsurgency situation described in the Manual our troops must be prepared to be greeted with a hand grenade OR a handshake. Is this a task for a high school dropout who gets into the infantry on a moral waiver?

We might pause here and contemplate the dilemma of the polar opposites of handshake and hand grenade. One represents enmity and death, the other friendship, mutual effort, positive action. If we take this example literally, it describes the impossible. If it is intended simply to counsel caution, it still invokes a context in which even great vigilance may not be enough. There have been numerous instances in Afghanistan where men in Afghan Army uniforms have suddenly fired on American soldiers working with them, standing next to them in fact. ${ }^{5}$ This illustrates the familiar problem in a counterinsurgency situation of being unable to count on the military we have trained to fight on our side.

Just as in Vietnam before we withdrew, American officials in Afghanistan speak of a competent Afghan military as an essential ingredient in our plans and describe progress optimistically. The view on the ground, as usual, suggests otherwise. In a firefight on October 3, 2009, one of the deadliest battles of the war, Afghan troops performed badly in every respect. ${ }^{6}$ Rather than throwing themselves into the fight that broke out when 300 insurgents attacked an isolated 
combat outpost, they cowered in their rooms. Worse, under cover of the chaos that ensued, they stole digital cameras and other personal belongings of Americans engaged in fighting. Of the 36 Afghans, 15 deserted. Well, that was 2009.

A year later, C. J. Chivers reported on the Afghan Army in the New York Times that "at the small-unit level, Western troops and journalists have documented their corruption, drug use, mediocre or poor fighting skills and patterns of lackluster commitment, including an unwillingness to patrol regularly and in sizable numbers, or to stand watch in remote outposts. At the higher levels, Western military officers often describe patronage, favoritism and an absence of managerial acumen, rooted in part in the pervasive culture of corruption and in widespread illiteracy. (Now, 14 percent of the combined force can read or write - at the third-grade level.)." ${ }^{7}$

This past July, as General Petraeus bid farewell to his position as commander in Afghanistan, he characterized the Afghan army and police as "increasingly credible" forces. ${ }^{8}$ Yet, out of 160 Afghan battalions, only one is considered able to function without US assistance. That's "increasingly credible"? We went into Afghanistan in 2001. After ten years, their army is only "increasingly credible"?

It's indisputable that the Afghan people have a long proud history as warriors, so could it be that, like the South Vietnamese troops of the past, they feel no enthusiasm for their corrupt central government and no allegiance to the rich Americans who could not help but communicate their sense of superiority to the troops they were training?

Even before we get to the digital cameras, size and appearance alone convey American superiority. In the documentary Restrepo, big, healthy Americans are juxtaposed with physically slight village elders with scraggly beards and bad teeth. Some are probably much younger than they look. And, as Tobias Wolff wrote in his Vietnam War memoir In Pharaoh's Army, the Tet attack proved to the Vietnamese that "for all our talk of partnership and brotherhood we disliked and mistrusted them, and that we would kill every last one of them to save our own skins" (Wolff 140).

Our caring about problematically friendly foreigners is always limited by so many factors: our own safety, money, time, other commitments, and--finally--will. They know and we know: our concern for these friendlies, however friendly they may be, can never be as great as our concern for ourselves. Whatever our official fiction, we may give them up at any time, and we WILL give them up at some point. This knowledge is unlikely to inspire their loyalty. As a contemporary gloss on this point, consider our shameful lack of help for those Iraqis who worked for us during the war and consequently are at risk in today's Iraq. While we drag our feet about letting them into this country, a number have already been murdered. 
A word now about the role of military acronyms in creating enabling fictions for counterinsurgency operations. Many such abbreviations are innocuous shortcuts--mos for military occupation specialty, for instance--but some also substitute an abstraction for a potentially unpleasant reality, collateral damage being one of the foremost examples. Just recently in a conference paper on our 19th century Indian Wars, a speaker remarked about a well-known massacre of noncombatants that "women and children were victimized by Army bullets." ${ }^{\prime 9}$ The reference to Army bullets is a little too vivid to be out-and-out military speak, but the passive construction and the attribution of agency to bullets rather than shooters makes this utterance a hybrid construction, halfway to "collateral damage."

The deviation of language from reality into fiction covers a multitude of sins in the military. William Calley, the officer held responsible for the My Lai massacre of March 16,1968, describes a conversation he had with the colonel he reported to when, after the massacre but before it become public knowledge, he received a promotion and became a community aid officer in a Vietnamese village: "Sir, I'm causing dissension here," Calley began. The colonel asked him, "Do you know how to solve it?" Calley replied sincerely: "No sir." The colonel: "Do you know my philosophy?" Calley: "Yes sir." Colonel: "And it is--?" Calley: "Solve it." In other words, Calley tells the reader, "The Colonel couldn't worry about it. Division didn't care. ... it wanted statistics, but it would never ask him, "How much dissension now?" Dissension looked bad" (Sack 143). So the only data quantified was positive, which naturally gave a somewhat skewed impression of the war that was actually being fought.

No one would be against solving problems: it just happened to be impossible in the situation Calley was in, which is why he had consulted his commanding officer. Similarly, when General Petraeus was the man of the moment in Iraq, he ended every day by inquiring of his staff, "How have we helped the Iraqi people today?" ${ }^{10}$ No doubt he genuinely hoped that the Iraqi people had been helped, and no doubt his subordinates gave him the answers he was looking for or got their behinds kicked. This is the man who said, "I don't do optimism or pessimism. I do realism." ${ }^{11}$ Perhaps we need an asterisk here to indicate realism as defined in the military.

Do people involved in a war understand the fictions that they themselves participate in? One might think that they couldn't help but know; however, the need to please superiors and follow prescribed procedures take priority over that understanding. An air force pilot in Vietnam knew that his bombing mission had destroyed a number of peasant huts rather than military structures, but the afteraction report had no category for civilian buildings destroyed--only military targets--so it was inevitable that whatever structures were destroyed would be counted as military (Schell 179-80). Further up the chain of command, there is an even stronger personal investment in going along: promotion and long-term 
career prospects depend on such fictions.

With counterinsurgency theoreticians it's different. I suspect they do believe their fictions because their ideas are never checked against facts, even when, as in the following example, facts are brought up. A recent book defending the war in Afghanistan begins with a series of acknowledged negatives: the war's long duration and lack of progress, its apt comparison to the Vietnam War. "In fact," the authors admit, "after all the mistakes that have been made to date, after all the years and lives and dollars that have been squandered, the Afghanistan war may turn out to be unwinnable." And now comes the leap of faith: "But it is too soon to be fatalistic" (O'Hanlon 61). Optimistic predictions follow, depending entirely upon President Karzai morphing into George Washington.

Similar pronouncements abound in the Counterinsurgency Field Manual. It describes counterinsurgency as "manpower intensive," meaning that a minimum requirement of force density should be twenty counterinsurgents for every thousand civilians. This number can include the host nation's military, in this case, Afghan soldiers, and its police. Most reliable sources place the population of Afghanistan at close to thirty million, which would require a counterinsurgent force of a million, five hundred thousand. The United States has 90,000 troops in Afghanistan, and the forty-seven other countries that have joined us altogether have little more than 33,000. Some of these allies have well under 100 boots on the ground: Austria, for example, has three, while our stalwart ally Tonga has sent 55. The Afghan army and police, as of 2010 , totaled 256,000 , with the usual promise that another 50,000 would be added by the end of this year. In short, the grand total is less than a third of what the Manual regards as necessary.

The more significant number comes out of another formula, not the ratio of counterinsurgents to inhabitants but that of terrorists killed to terrorists created. The Manual asserts that an operation is a failure if it kills five terrorists but creates fifty more (45). Such operations, where civilians are collateral damage, happen all the time, leaving a legacy of bitterness that can be exploited by the insurgents. Moreover, the enemy is rarely a static entity. Various sources have stated that there are few Al Qaeda operatives left in Afghanistan, possibly as few as a couple of hundred. The military mindset is to think in terms of neutralizing that number. But if others take the place of the two hundred eliminated, the job continues. This was the pattern in Vietnam. North Vietnam had a large reservoir of draft-age people to replace whatever losses they sustained. And we knew this at the time.

Since the Afghan Taliban is fed by jihadists from a Muslim population of more than a billion people, part of the coalition strategy has been to win some over to our side. When individual Afghan fighters have renounced the Taliban, however, interviews have determined that it has been because they objected to killing fellow Afghans. Their hatred of Americans remained constant. ${ }^{12}$ it might seem to be self-evident that when you want people to like you, you should not be 
"victimizing them with bullets." If we regarded Afghans as people like ourselves, it would be obvious to us that this policy generates ill will of the sort that no amount of good intentions will overcome.

And yet, if a choice must be made, the military will default to killing. There is the huge fiction that an American infantryman of average intelligence who has been dropped into a country where everyone not in his unit is, as far as he's concerned, a hostile alien, and in any case he can't tell which one is offering the handshake and which one has the hand grenade--that this young soldier can win the hearts and minds of these dark-skinned folks by being as adept at nationbuilding as he is at killing people and breaking things. Even Jimmy Carter might have a problem in such a context, but this is an undereducated young person, often with a troubled history, who has had 8 weeks of basic training and 8 weeks of advanced infantry.

When the war is waged by remote control, as in the case of drone attacks, resentment is likely to be particularly strong. Any number of civilians have been mistakenly targeted or killed accidentally, but every so often we succeed in hitting an Al Qaeda target. For our war machine, the military objective outweighs the civilian cost. Afghans are likely to feel differently. The general public might be surprised to learn how much is tolerated under the rubric of collateral damage. The success of a mission, or even the goal of a mission, whether successful or not, almost always justifies to the military way of thinking whatever collateral damage takes place.

This principle has been consistently upheld by military courts. It includes, as was widespread in Vietnam, the execution of civilians who are in the path of a mission. In Iraq such an incident occurred when a civilian wandered into an area where Americans were setting up a sniper position. The officer in charge ordered a soldier to kill the unlucky Iraqi, planted a weapon on the body, and radioed his superior that the position had been attacked. ${ }^{13}$

To my civilian mentality, execution has a kind of culpability that differs from the panicked killing by frightened, trigger-happy soldiers who believe, however foolishly, that they are under enemy attack--the kind of response that tragically killed Pat Tillman in Afghanistan. I've wondered why the snipers couldn't have restrained and gagged the civilian until their operation was over. I'm sure he would have preferred it. Certainly his family would have. They testified eloquently at the court-martial about the loss of this husband and father of four. To no avail: the officer who gave the order was exonerated although-inconsistently--the sniper triggerman who obeyed the order was convicted. It wasn't reassuring to be told by a witness at the court-martial of the triggerman that if the actions of every combat serviceman in Iraq were subjected to the same scrutiny as the defendant's, "we would have thousands" of cases.

This man stated that the shooting "was a result of Iraq's violent environment and the often difficult and confusing choices that servicemen make 
daily." This isn't inaccurate: it's true that the counterinsurgency world, where handshakes and hand grenades may be ambiguously proferred, is a dangerous one. The choice made in this killing, however, does not seem to be difficult or confusing so much as wrong and convenient. Had it been according to the rules of engagement, as the snipers claimed, there would have been no need to pretend that they had been attacked.

We should not cherish the illusion that civilian public relations or good works will ever be the military's first choice. In a very clear cut example of choosing between winning hearts and minds and killing, the senior American civilian adviser in Quang Nam Province, Vietnam, wrote on March 18, 1968, to the commander of American troops in Vietnam, General William Westmoreland, to beg that Korean troops be removed from the province: "The Vietnamese peasants are, of course, deathly afraid of the Koreans. Many say that they prefer the VC to the Koreans ... [This] may actually be causing an increase in VC sympathizers throughout the Korean TAOR [tactical area of operations]" (Greiner 190). Even the South Vietnamese officials of the province, usually so indifferent to the concerns of their own people and compliant towards the American military, even these officials asked that the South Koreans be sent elsewhere.

Yet, Westmoreland refused to remove either the marauding South Koreans or rogue American troops. Fighting a losing war, he wanted and needed their aggressive edge. That such a victory would be built on the bodies of apolitical rural villagers was an aspect of the situation best ignored. This military mindset still dominates.

So we might say that one of the problems of counterinsurgency is that micro and macro are inevitably out of synch. For the overall effort to succeed, we need the support of the people. But in the microcosm of military action, where quantifiable data is the major measurement of progress, we need to do things that will create hostility among the very people we want to get on our side. That macro and micro can function smoothly together is one of the most salient fictions of counterinsurgency.

This brings up a significant aspect of our way of waging war today. Our military effort not only depends on huge numbers of foreign contract workers to staff American bases, it depends on money to substitute for other kinds of effort.Money has its limitations in counterinsurgency. In 2007, we paid leaders in the Sunni Triangle of Iraq to join our effort. Their repudiation of AI Qaeda became known as the Anbar Awakening, a change of allegiance that combined with the troop surge of that year to alter the dynamic of the war.

Several points need to be made about this policy. First, it coincided with the Shiite militia leader Moqtada al-Sadr announcing a six-month ceasefire and standing down his attacks against Iraqi Sunnis and coalition forces; then he extended the cease-fire for another six months. Second, Iraqi Sunnis were 
already disenchanted with Al Qaeda, which mostly consisted of non-Iraqis enforcing a harshly austere form of Islam on them. The Sunnis were receptive to the American overture of money because they were ready to throw off Al Qaeda: "Absent those two necessary conditions, there would have been no let up in the level of violence despite the surge. ${ }^{14}$

Moreover, the money wasn't going to be paid forever. If you buy someone's allegiance with money, be prepared for the allegiance to disappear when the payments end. And in the triumphalist narrative about the success of the surge, everyone seems to have forgotten that the point of the surge was to tamp down the violence enough to move the political process along. How's that working out? Four years down the road after the surge, the news is still more negative than not: a New York Times headline of August 16 read: "A series of attacks sent the message to Iraq and the United States that after tens of thousands of lives lost and hundreds of billions of dollars spent, insurgents remain a threat." ${ }^{15}$ Such terrorist bombings occur with depressing frequency; the two politicians who are supposed to share power don't speak to each other; consequently, the government of Iraq is almost as dysfunctional as our own. On almost every key issue, no progress has been made, and the reappearance of Muktada al-Sadr with a plan to gain political power is an ominous development-and not merely because he hates the United States.

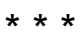

The evening of May 1, during a tense Phillies-Mets game, fans began chanting USA, USA. Given the omnipresence of Blackberries and Ipads these days, they knew before the announcers did what had happened. The players on the field, unlike most people in our society at all times, were out of reach of the internet, so they were the last to know: Bin Laden was dead. Had I been in the stands rather than at home in front of the tv, I would have been chanting, too. Such moments inspire patriotic outbursts, especially when you're part of a like-minded group. Americans were bound to rejoice in the death of a man who, for a decade, had personified terrorism for us.

As a historian, I also made a connection to a story I had read that very morning that illustrates the profound disconnect between counterinsurgency as understood by officials at the top of the hierarchy and as practiced by those on the ground. ${ }^{16}$ The story reports on the trial of a nineteen-year-old sergeant in the 5th Stryker Brigade, who, along with some like-minded soldiers, murdered three random civilians in Afghanistan last year and attempted to disguise each killing as a combat incident. Until it became impossible to ignore, the sergeant's immediate superiors had followed a time-honored military policy of overlooking suspicious circumstances and accepting the explanation that the Americans had been attacked. Locals knew better: the first victim was a fifteen year old farmer who had been working in his family's field until called over by the soon-to-be murderers. The other two Afghans killed were known to be peaceful and 
unacquainted with weapons, the least likely villagers to suddenly attack a group of heavily armed American soldiers.

Only four weeks before the killings began, the chairman of the Joint Chiefs of Staff, Admiral Mike Mullen, paid a heavily publicized visit to the area. The military's strategy of counterinsurgency, he reminded members of 5th Stryker Brigade, required them to win hearts and minds by protecting the population. "If we're killing local civilians," he cautioned, "we're going to strategically lose." In contrast, Corporal Jeremy Morelock, one of the soldiers involved in the killings, told Army investigators, "None of us in the platoon--the platoon leader, the platoon sergeant--no one gives a fuck about these people." While Morelock and his buddies were committing these murders, documenting their actions with photographs of themselves reminiscent of the notorious Abu Ghraib photos-smiling over the corpses and taking severed fingers as trophies--their commanding officer was meeting with Afghan village officials as part of the American counterinsurgency strategy of winning the people to our side.

\section{$\underline{\text { Notes }}$}

${ }^{1}$ General Shinseki, chairman of the Joint Chiefs of Staff, publicly indicated that the approaching Iraq War would require far more troops than Secretary of Defense Rumsfeld believed; General Taguba was given the unenviable task of producing a report on the Abu Ghraib scandal.

${ }^{2}$ Petraeus and Amos, "Forward," The U.S. Army/Marine Corps Counterinsurgency Field Manual (Chicago: University of Chicago Press, 2007): xlv. Print.

${ }^{3}$ Nagl on "The World," PRI, March 2009, cited by Vlahos, "Gian Gentile:

Exposing Counterfeit Coin," antiwar.com (6 May 2005).

${ }^{4}$ Gentile: "Misreading the Surge ..." World Politics Review (4 Mar. 2008).

${ }^{5}$ Rubin and Rahimi, "Afghan Military Officer Kills 8 U.S. Service Members," New York Times. (28 Apr. 2011); Rubin, "Afghan Who Killed 6 G.I.'s Was Trusted Officer" (1 Dec. 2010); Nordland and Rihimi, "Afghan Officer Turns Against U.S. Soldiers, Killing 2," (5 Apr. 2011).

${ }^{6}$ Lardner, "Afghan Soldiers Ran, Hid during Attack," (10 June 2011).

${ }^{7}$ Chivers, "Gains in Afghan Training but Struggles in War," The New York Times, (12 Oct. 2010).

${ }^{8}$ General David Petraeus, cited in Bennhold, "Afghanistan War 'Fragile' but Doable, General Says," New York Times (July 21, 2011).

${ }^{9}$ Audience participant, Little Big Horn Associates annual symposium, Oklahoma City, OK, June 18, 2011.

10 David Petraeus cited in John A. Nagl, "Forward to the University of Chicago Press Edition," The U.S. Army Marine Corps Counterinsurgency Field Manual, p. $\mathrm{xV}$. 
${ }^{11}$ Harnden, "Afghanistan: Gen. Petraeus says U.S. forces will remain until end of 2014," The Telegraph (August 26, 211).

${ }^{12}$ Corey Flintoff, "Former Taliban reconcile with Afghan Government," Morning Edition NPR, March 30, 2011.

${ }^{13}$ All information on this case, including citations, has been taken from Moore,

"G.I. Gets 10-Year Sentence in Killing of Unarmed Iraqi," New York Times (11

Feb. 2008).

${ }^{14}$ Gentile, "Misreading the Surge ...."

${ }^{15}$ Schmidt, "U. S. Report Finds Security Deteriorating in Iraq," New York Times (31 July 2011).

${ }^{16}$ Details of this event and quotations are taken from Boal, "The Kill Team: How

U. S. Soldiers in Afghanistan Murdered Innocent Civilians," Rolling Stone (27 Mar.2011).

\section{Works Cited}

Bennhold, Katrin. "Afghanistan War 'Fragile' but Doable, General Says." New York Times. 21 July 2011. Web. 19 Aug. 2011.

Boal, Mark. "The Kill Team: How U.S. Soldiers in Afghanistan Murdered Innocent Civilians." Rolling Stone (27 Mar. 2011). Web. 24 Aug. 2011.

Chivers, C. J. "Gains in Afghan Training but Struggles in War." New York Times. 12 Oct. 2010. Web. 22 Aug. 2011.

Frank, Thomas. "Easy Chair: Required Reading," Harper's (June 2011): 9-11. Print.

Gentile, Gian P. "Misreading the Surge Threatens U.S. Army's Conventional Capabilities." World Politics Review. Web. 22 Aug. 2011.

Greiner, Bernd. War Without Fronts: The USA in Vietnam. Hamburg: Hamburger Edition, 2007. Trans. Anne Wyburd with Victoria Fern. New Haven: Yale University Press, 2009. Print.

Harnden, Toby. "Afghanistan: Gen. Petraeus says U.S. forces will remainn until end of 2014." Telegraph. 24 June 2011. Web. 26 Aug. 2011.

Hetherington, Tim and Sebastian Junger. Restrepo: One Platoon, One Valley, One Year. Outpost Films: 2010.

Lardner, Richard. "Afghan Soldiers Ran, Hid during Attack." Associated Press Archive. 10 June 2011. Web. 28 Aug. 2011. 
Mayer, Jane. "The Secret Sharer: Is Thomas Drake an enemy of the state?" The New Yorker (May 23, 2011): 48. Print.

Moore, Solomon. "G.I. Gets 10-Year Sentence in Killing of Unarmed Iraqi." New York Times. 11 Feb. 2008. Web. 20 Aug. 2011.

Morning Edition. National Public Radio. Washington, D.C.: Public Broadcasting System: 30 Mar. 2011. Web. 19 Aug. 2011.

Norland, Rod and Sangar Rihimi. "Afghan Officer Turns Against U.S. Soldiers, Killing 2." New York Times. 5 Apr. 2011. Web. 17 Aug. 2011.

O'Hanlon, Michael E. and Hassina Sherjan. Toughing It Out In Afghanistan. Washington, D.C.: Brookings Institution Press, 2010. Print.

Rubin, Alissa. "Afghan Who Killed 6 G.I.'s Was Trusted Officer." New York Times. 1 Dec. 2010. Web. 3 Aug. 2011.

Rubin, Alissa J. and Sangar Rahimi. "Afghan Military Officer Kills 8 U.S. Service Members." New York Times. 28 Apr. 2011. Web. 3 Aug. 2011.

Sack, John. Lieutenant Calley: His Own Story. New York: Viking, 1970. Print.

Schell, Jonathan. The Military Half: An Account of the Destruction in Quang Ngai and Quang Tin. New York: Knopf, 1968. Print.

Schmidt, Michael S. "U.S. Report Finds Security Deteriorating in Iraq." New York Times. 31 Jul 2011. Web. 7 Aug. 2011.

The U. S. Army/Marine Corps Counterinsurgency Field Manual. Chicago: University of Chicago Press, 2007. Print.

Vlahos, Kelley B. "Gian Gentile: Exposing Counterfeit Coin." Antiwar.com. 5 Jun. 2009. Web.17 Aug. 2011.

Wolff, Tobias. In Pharaoh's Army: Memories of the Lost War. New York: Viking, 1994. Print. 